\title{
The Analysis of Modern Retail Growth
}

\section{toward Traditional retail store in Berastagi as}

\section{a Tourist City}

\author{
Wan Suryani \\ Faculty of Economy \\ Universitas Al Washliyah \\ Wansuryani77@yahoo.com
}

\author{
Febrilian Lestario \\ Faculty of Economy \\ Universitas Pembangunan Panca Budi
}

\begin{abstract}
This research aims to reveal and overview the impact of modern retail business' growth toward the development of traditional retail store in Berastagi as a tourist city. The hypothesis of this research is The growth of modern retail business significantly impacts the growth of traditional retail store in Berastagi as a tourist city. The tool of collecting the data is by using questionnaire with the Likert scale. The population is the merchants of traditional retail store as many as 79 respondents. The data analysis utilized qualitative analysis with simple linear regression model. The result of this model is expected to be the source of evaluation for the local government in formulating policies of franchise and traditional business model. Moreover, it is expected as well that this research can be the additional information in the making of teaching material and be published in the journal.
\end{abstract}

Keywords-The growth of modern retail business; the development of traditional retail store

\section{INTRODUCTION}

The need of traditional market has a positive impact toward the society surrounds it. This leads to the fact that traditional market has become the contributor of the growth of city's economy which equipped by the K- Society and K- Economy in order to success the government' program of information and knowledge-based society.

The emergence of modern markets such as Indomaret, Alfa Midi and Alfa Mart is thought to marginalize the traditional markets in urban area. Based on the result study of [2], modern market grows $31.4 \%$ per year meanwhile the traditional market shrinks to $8 \%$ per year. The result of the study of the Ministry of Small and Medium enterprises with PT Solusi Dinamika shows that the emergence of modern market has threatened the existence of traditional market. The impact of modern market toward traditional market lies on the shrinking of sales turnover.

Berastagi city is a tourist destination with a potential to develop very fast for its growth in economy, trade, and the establishment of universities and tourist spots has triggered the influx of local and international tourists to come to the city. This growth triggers the complex need of life for urban people in Berastagi city so that the emergence of modern retail market is really a promising business.

Before the establishment of a modern retail market, the physical consideration needs to be taken. Viewing from the service of traditional market and modern retail market, it is completely different, either from the price and the products offered. The service and the convenience of the modern market outperform the traditional market. Based on the background above, the authors were keen to do the research by the title "The Analysis of Modern Retail Development toward Traditional retail store in Berastagi as a Tourist City." 


\section{LITERATURE REVIEW}

\section{A. Modern and Traditional Market}

The market is the place where a group of sellers meets their costumers in order to do the transaction or exchange service. There are five functions of market according to [1], namely :

a. Setting the value

b. Distributing the goods

c. Organizing productions

d. Rationing

e. Preserving and Preparing Future need.

According to [3], the general problems faced by traditional market are:

a. The crowd of the merchants that can't be accommodated

b. It has filthy image

c. Fast food seems unhygienic

d. The growing modern retail market is a serious threat to traditional market.

e. Low awareness amongst the merchants to develop its enterprises and to locate its designated place.

f. Low awareness to pay the retribution

g. The market which takes place only in one day.

\section{B. The Impact of Modern Retail market} toward traditional market.

Virtually, modern and traditional market has their own advantages where they have different segmentation in one and another. There is a bargaining process in traditional market which enables the creation of personal and emotional relationship between the seller and customer. This is not happening in modern market because the price is fixed labeled by the price tag. One of the advantages of modern market over traditional is the ability to establish a long-term cooperation with major distributors that eventually enables the efficiency in a large economy scale. There are also some strategies applied in modern market such as discounted price, price discrimination over time, nonprice strategy amongst advertised items, long operation hours, wholesale purchase and free parking.

The threats emerge from the existence of modern retail market are: first, shutting down the traditional market because there is a consumer shift. The very close location between traditional and modern market has caused the consumers shift from traditional to modern market due to the advantages possessed by modern market over traditional market. Second is related to local economy. Money circulation in the local is mostly derived from small and medium enterprises and with the decreasing of these small and medium enterprises and traditional market; eventually it has lead to little contribution.

\section{RESEARCH METHODOLOGY}

\section{A. Research Material}

This research aims to focus on the material of the impact of the growth in modern retail business toward the development of traditional retail store in Berastagi as a Tourist city.

\section{B. Types and the Scope of the Research}

This research has been conducted by using case study approach which is supported by survey. The survey is a research which obtains the sample from one population by using questionnaire as the tool to collect the main data and generally has utilized quantities method.

This research was being analyzed by using simple linear regression, which is by taking purposive sample of 79 merchants of traditional market from the total population spread in 10 villages in Berastagi city. The name of the villages are:

1. Doulu Village

2. Gundaling I Village

3. Gundaling II Village

4. Gurusinga Village

5. Raya Village 
6. Rumah Brastagi/Berastagi Village

7. Sempajaya Village

8. Tambak Lau Mulgap I Village

9. Tambak Lau Mulgap II Village

IV.RESULT AND DISCUSSION

Table 1. Validity test of the questions

\begin{tabular}{|c|c|c|c|c|}
\hline \multicolumn{5}{|c|}{ Correlations } \\
\hline & & $\mathrm{x} 1$ & $\mathrm{x} 2$ & $X$ \\
\hline \multirow[t]{4}{*}{$\mathrm{x} 1$} & Pearson & & & \\
\hline & Correlation & 1 & .541 & .884 \\
\hline & $\begin{array}{l}\text { Sig. }(2- \\
\text { tailed })\end{array}$ & & .000 & .000 \\
\hline & $\mathrm{N}$ & 79 & 79 & 79 \\
\hline \multirow[t]{4}{*}{$x 2$} & Pearson & & & \\
\hline & Correlation & .541 & 1 & .871 \\
\hline & $\begin{array}{l}\text { Sig. (2- } \\
\text { tailed) }\end{array}$ & .000 & & .000 \\
\hline & $\mathrm{N}$ & 79 & 79 & 79 \\
\hline \multirow[t]{4}{*}{ X } & Pearson & * ** & 西* & \\
\hline & Correlation & & $.8 / 1$ & 1 \\
\hline & $\begin{array}{l}\text { Sig. }(2- \\
\text { tailed })\end{array}$ & .000 & .000 & \\
\hline & $\mathrm{N}$ & 79 & 79 & 79 \\
\hline \multicolumn{5}{|c|}{$\begin{array}{l}\text { **. Correlation is significant at the } 0.01 \text { level (2- } \\
\text { tailed). }\end{array}$} \\
\hline
\end{tabular}

From the calculation result of output SPSS, it can be seen that the correlation in respective sectors toward the total of construct score shows a significant result. Hence, it can be concluded that each question for the growth of modern business retail is valid.

The result of validity test for the questions of growth in modern business retail toward the development of traditional market can be seen in the table below:
Table 2. Validity test of questions on the development of traditional retail store

Correlations

\begin{tabular}{|c|c|c|c|c|}
\hline & & y1 & y2 & Y \\
\hline \multirow[t]{3}{*}{ y1 } & $\begin{array}{l}\text { Pearson } \\
\text { Correlation }\end{array}$ & 1 & $.658^{* *}$ & $.886^{* *}$ \\
\hline & Sig. (2-tailed) & & .000 & .000 \\
\hline & $\mathrm{N}$ & 79 & 79 & 79 \\
\hline \multirow[t]{4}{*}{ y2 } & Pearson & & & \\
\hline & Correlation & .658 & 1 & .900 \\
\hline & Sig. (2-tailed) & .000 & & .000 \\
\hline & $\mathrm{N}$ & 79 & 79 & 79 \\
\hline \multirow[t]{4}{*}{ Y } & Pearson & $886^{* *}$ & $00 \Omega^{* * *}$ & 1 \\
\hline & Correlation & & & 1 \\
\hline & Sig. (2-tailed) & .000 & .000 & \\
\hline & $\mathrm{N}$ & 79 & 79 & 79 \\
\hline
\end{tabular}

**. Correlation is significant at the 0.01 level (2tailed).

The result of hypothesis regression

The hypothesis states that the growth of modern retail store $(\mathrm{X})$ has significantly impacted the traditional retail store $(\mathrm{Y})$ in Berastagi as a Tourist city.

Table 3. The result of Regression Coefficient Test

\begin{tabular}{|c|c|c|c|c|c|}
\hline \multicolumn{6}{|c|}{ Coefficients $^{\mathrm{a}}$} \\
\hline \multirow[b]{2}{*}{ Model } & $\begin{array}{c}\text { Unstanda } \\
\text { rdized } \\
\text { Coefficie } \\
\text { nts }\end{array}$ & \multicolumn{2}{|c|}{$\begin{array}{l}\text { Standardiz } \\
\text { ed } \\
\text { Coefficient } \\
\text { s }\end{array}$} & \multirow[t]{2}{*}{$\mathrm{t}$} & \multirow[t]{2}{*}{ Sig. } \\
\hline & & $\begin{array}{l}\text { Std. } \\
\text { Error }\end{array}$ & $\begin{array}{l}\mathrm{Be} \\
\text { ta }\end{array}$ & & \\
\hline $\begin{array}{ll}1 & \text { (Cons } \\
& \tan \mathrm{t})\end{array}$ & 1.566 & .834 & & 1.878 & .064 \\
\hline $\mathrm{X}$ & .771 & .115 & $\begin{array}{l}.6 \\
07\end{array}$ & 6.696 & .000 \\
\hline
\end{tabular}

a. Dependent

Variable: Y 
Based on table 5.6., then the equation of simple regression analysis is:

$$
\hat{\mathrm{Y}}=1.566+0.771 \mathrm{X}_{1}+\varepsilon
$$

From the equation above it can be seen the growth of modern retail $(\mathrm{X})$, and to influence the development of traditional retail (Y) in Berastagi as tourist city.

The value of determination coefficient of $\left(\mathrm{R}^{2}\right)$ was used to measure the sheer impact of free variable in modern retail growth $(\mathrm{X})$ toward the development of traditional retail store $(\mathrm{Y})$ in Berastagi as a Tourist City.

Table 4. test result of hypothesis determination

\begin{tabular}{|l|r|r|r|c|}
\hline & & & & Std. \\
& & & & \\
Adjusted & $\begin{array}{c}\text { Model Summary } \\
\text { the } \\
\text { the } \\
\text { Model }\end{array}$ \\
& R & R Square & R Square & Estimate \\
\hline 1 & $.607^{\mathrm{a}}$ & .368 & .360 & 1.39119 \\
\hline
\end{tabular}

a. Predictors: (Constant), X

b. Dependent Variable: Y

Based on the table 5.7. it can be seen that coefficient determination scores as 0.360. This shows that the ability of modern retail growth variable $(\mathrm{X})$ to explain its influence on the development of traditional retail store in Berastagi as a Tourist city as much as $36.0 \%$. While the rest of $64.0 \%$ is the influence of other free variables which is not studied (Variabel Dummy $=e$ ), for examples: price, customs, types of products and etc.

\section{CONCLUSION}

From the result of SPSS calculation, it shows that the growth of modern retail business has positively impacted the development of traditional retail store in Berastagi as a tourist city. From the direct observation in the field, generally, it can be concluded that the existence of franchise business minimarket surrounds traditional retail store has impacted toward the development of traditional retail store. Even they no longer have costumers. But from the observation, there are also traditional retail stores that have been very resilient amidst the growth of modern retail market such as alfa mart and indomaret. Product diversification offers many choices to consumers and this also significantly impacts to the development of traditional retail store. The consumers feel more served and satisfied with the variety of the products they want to purchase.

\section{REFERENCES}

[1] Wijayanti Tri (2011). Pasar tradisional dan pasar modern. Jakarta: PT Gramedia

[2] A.C. Nielsen. (2005). Asia Pasific Retail and Shopper Trends2005,

ttp://www.acnielsen.de/pubs/documents/Retailand ShopperTrendsAsia2005

[3] Kuncoro, Mudrajad (2006), Strategi: Bagaimana Meraih Keunggulan Kompetitif.Jakarta: Erlangga.

[4] David, Fred. 2006. Manajemen Strategis. Edisi Sepuluh. Salemba Empat, Jakarta.

[5] Abdullah, Maskur. 2005. Lilitan Masalah Usaha Mikro kecil, Menengah (UMKM) dan Kontroversi Kebijakan. Medan: Bitra Indonesia.

[6] Alma, Buchari. 2004. Pengantar Bisnis. CV. Alfabeta, Bandung.

[7] Ball, Donal A, Mc Culloch \& Wendell H. 2001. Bisnis Internasional. Jakarta: Penerbit Salemba Empat.

[8] Bararualuo, Frans. 2001. Kajian Strategis Pengelolaan dan Keunggulan Bisnis Usaha Kecil di Indonesia.Yogyakarta: Aditya Media.

[9] Longenecker, Justin G, Carlos W.J. \& William Petty. 2001. Kewirausahaan : Manajemen Usaha Kecil. Jakarta: Penerbit Salemba Empat.

[10] Anoraga, Panji. 2002. Koperasi, Kewirausahaan, dan Usaha Kecil. Jakarta: Rineka Cipta.

[11] Dirgantoro, Crown. (2001). Manajemen Strategik : konsep, kasus dan implementasi. Grasindo, Jakarta.

[12] Madura, Jeff. (2001). Pengantar Bisnis. Edisi Pertama. Salemba Empat, Jakarta.

[13] Robinson, Pearce. (2001). Strategic Management : Formulation, Implementation and Control. Seventh edition. McGraw. Hill Book International.

[14] Hafsah, Muhammad Jafar. 1999. Kemitraan Usaha. Jakarta :Pustaka Sinar Harapan.

[15] Krugman, Paul R. 1996. Ekonomi Internasional: teori dan kebijakan, Edisi Kedua: Jakarta, Rajawali Per. 